https://doi.org/10.18485/dpls_pld.2020.6.ch8

371.3

\author{
Dragica Žugić \\ Univerzitet Donja Gorica
}

\title{
THE ROLE OF THE STUDENT-TEACHER RELATIONSHIP IN THE LIVES OF STUDENTS AT UNIVERSITY LEVEL
}

\begin{abstract}
Holistic approach to education points out the importance of the affective and inter-relational qualities of the students and teachers (Cunningham, 2001; Gibbs, 2006). In the modern classroom, both teachers and students represent the main actors in the process of education and conversations about education always include remarks, anecdotes or stories about particular teacher-student relationships. The influence of the teacher-student relationship correlates with three different spheres of the student: their character, knowledge and understandings, and skills, or, as Palmer (1997) described, the student's "head, heart and hands". The purpose of this article is to explore the role of the student-teacher relationship from the perspective of students at university level. Quantitative data were collected through the ClassMaps Survey (CMS) and analyzed for themes in order to provide a more comprehensive understanding of the dynamics and importance of the student-teacher relationship in the lives of students at university level. These themes comprised the following characteristics: a sense of humor; constant help; active listening; value for the group as well as the individual; the inclusion of games for learning; and the use of spoken and written encouragement. In addition to setting the objectives for teachers, these themes may also be used to help H\&R administrators to choose teachers more effectively.
\end{abstract}

Keywords: holistic approach, teacher's role, student-teacher relationship, relational connectedness

\section{Introduction}

The impetus for this research paper was the situation which inspired me to start dealing with the relationship between teachers and students at university level and what is the students ' perception of a modern teacher in the world of new technology when (s)he is not the only one who can 
provide them with knowledge and information and knowing that they are just a "click away" from the exciting world of the Internet.

Most educationalists and institutions are still engaged with the question of how teacher influence a student's achievements. One of them is The Gates Foundation ${ }^{1}$ which is currently spending millions of dollars trying to "uncover and develop a set of measures that work together to form a more complete indicator of a teacher's impact on student achievement." Districts across the country are experimenting with new ways to evaluate what teachers do - and how they do it. And the Obama Administration is giving states an incentive to undertake such work as part of its Race to the Top Fund ${ }^{2}$ within which the Department ask states to advance reforms around four specific areas:

- Adopting standards and assessments that prepare students to succeed in college and the workplace and to compete in the global economy;

- Building data systems that measure student growth and success, and inform teachers and principals about how they can improve instruction;

- Recruiting, developing, rewarding, and retaining effective teachers and principals, especially where they are needed most; and

- Turning around our lowest-achieving schools.

The importance of the interpersonal relationship between students and teachers has been widely recognized in research addressing preschool, primary and secondary education (Bernstein-Yamashiro \& Noam, 2013; Roorda et al. 2011). However, teacher-student relationship (TSR) at institutions of higher education has been less comprehensively and less systematically examined by researchers especially in our region even though we all know that one of the purposes of the Bologna Declaration is quality assurance of higher education ("Standards and Guidelines for Quality Assurance in the European Higher Education Area" adopted in 2005) and its ultimate goal is to enhance the quality of teaching and research.

\section{Theoretical background}

The relationship between teachers and their students has always been essential in the educational process. Very often we ask ourselves

\footnotetext{
${ }^{1}$ Retrieved October 7, 2018, from https://www.gatesfoundation.org/

${ }^{2}$ Retrieved October 7, 2018 from https://www2.ed.gov/programs/racetothetop/index.html

${ }^{3}$ Retrieved October 8, 2018 from https://enqa.eu/wp-content/uploads/2015/11/ESG_2015.pdf
} 
what should be the relationship between a teacher and a student in a teaching-learning environment? Master-slave; benefactor-supplicant; autocrat-subject; elected official-elector; governor-governed; operatormachine; parent-child; or some other...?. Being individual as we are each teacher has his/her own philosophy that governs his/her behavior towards his/her students.

According to Kelly et. al. (1983) relationships in general represent "strong, frequent, and diverse interdependence that lasts over a considerable period of time" ". In the developmental literature we can find definitions which often include the qualities of a relationship, such as trust, intimacy, and sharing; the presence of positive affect, closeness, and affective tone; and the content and quality of communication (Collins \& Repinski, 1994; Laible \& Thompson, 2007). With regard to teacher-student relationships, they are defined as caring and authentic relationships between teachers and students. However, Pianta (1999) in his book "Enhancing relationships between children and teachers" described Student-teacher relationshi$p s$ as "emotions-based experiences that emerge out of teachers' on-going interactions with their students". Another author, Wentzel (2009), said in his article "Describing Students' relationships with teachers as motivational contexts" that the nature and quality of students' relationships with their teachers play a critical and central role in motivating and engaging students to learn. According to Vygotsky (1978) and his sociocultural theory the teacher's role in a socially mediated learning process is to scaffold the student's learning.

The approach which points out these affective and inter-relational qualities of the students and teachers is the holistic approach and education in a broader sense (Cunningham, 2001; Gibbs, 2006). Education which is holistic can recognise the relational connectedness of the teacher-student relationship and according to Miller (2000) the characteristics of holistic education are the following:

1. It nurtures the development of the whole person

2. It revolves around relationships (egalitarian, open, and democratic relationships)

3. It is concerned with life experiences (instead of "basic skills")

4. It "recognizes that cultures are created by people and can be changed by people"

\footnotetext{
${ }^{4}$ Kelley, H. H., Berscheid, E., Christensen, A., Harvey, J. H., Husten, T., Levenger, G., McClintock, E., Peplau, A., \& Peterson, D. (1983). Close relationships. San Francisco: Freeman.
} 
5. it is founded upon a "deep reverence for life and for the unknown (and never fully knowable) source of life."

Holistic education upholds two principles (Miller, 2000) which means that a learning that connects the person to the world must start with the person and not some abstract image of the human being. That person might be a unique, living, breathing boy or girl, young man or woman (or mature person) who is in the teacher's presence. Each person represents actually a dynamic constellation of experiences, feelings, ideas, dreams, fears, and hopes. Secondly, we must respond to the learner with an open, inquisitive mind and a sensitive understanding of the world he or she is growing into. The educationalists Otero and Chambers-Otero (2004) find that the link between relationship and a holistic connection is explicit because "we cannot continue to make a commitment to educating the whole person while ignoring the relationships in which all learning occurs."

In the educational context there is a concern for the education of the whole person which necessitates a concern for the relational connectedness and which describes a basic bond of relationship (Bennett, 1997; Palmer 1997). Moreover, this connectedness in relationship has a holistic quality and it is influencing the whole person. cassa (1997:2) in his article The heart of a teacher writes about relational connectedness and the heart as follows: "The connections made by good teachers are held not in their methods but in their hearts, meaning heart in the ancient sense, the place where the intellect and emotion and spirit and will converge in the human self."

In the similar way, Miller (2000) believes that the educational process calls out and impacts teachers' and students' souls. What distinguishes holistic education from other forms of education, as Martin and Forbes (2004) stated, are its objectives, its focus on experiential learning, and the significance that it places on relationships and primary human values within the classroom environment.

\section{What makes a good teacher a good teacher?}

Carl Rogers (1967) might say: Respect, empathy and authenticity. According to his Facilitation Theory (1967) which sees the teacher as the key role in the process of learning, but not as a walking textbook transmitting its contents, but as the facilitator of learning. The 
facilitation as he explained means the teacher's attitudes in his or her personal relationship with the students. Thus Rogers recommends three attitudinal qualities which are necessary for facilitative practice (both in counseling and education). These so-called core conditions are

- Realness which means being himself, not denying himself and the teacher must be a real person who is aware of his or her feelings and is able to communicate them appropriately, no matter how exactly he or she feels does he feel. The teacher should not be just a role in the play of education, "a faceless embodiment of a curricular requirement or a sterile tube through which knowledge is passed from one generation to the next."

- Prizing, acceptance, trust which refers to teacher's caring about the student and his or her acceptance of student's feelings.

- Empathy or being able to walk in others shoes. This means that a teacher has to understand and not judge or evaluate student's perspective in the learning process and his/her reactions from the inside.

Palmer (1997:1-18) describes good and effective teachers as those who develop relationships with students that are emotionally close, safe, and trusting. Those teachers provide access to instrumental help, and foster caring in classrooms. These relationship qualities are considered crucial in the development of students' motivational orientations for social and academic outcomes, in the student's emotional wellbeing and a positive sense of self, and in their engagement in positive social and academic activities.

With regard to the question What makes a good teacher? Jeremy Harmer (1998:1-3) conducted a research with teachers and students from different language schools and nationalities and concluded "that the greatest number of students` responses to this question were not so much about teachers themselves but rather about the relationship between the teacher and the students."

Even though TSR is not typically regarded as a primary attachment relationship, attachment theory (AT) and its authors Cassady \& Shaver (2008) imply that these relationships would be fairly in accordance with the quality of parent-child attachments.

\footnotetext{
${ }^{5}$ Rogers, C. (1967). The Interpersonal Relationship in the Facilitation of Learning. In Humanizing Education: The Person in the Process. Ed. T. Leeper. National Education Association, Association for Supervision and Curriculum Development, 1-18.
} 


\section{The Bologna process and Institutions of Higher Education in Montenegro}

Having signed the Bologna Declaration in 2003 Montenegro has started with intensive high education reforms. It brought the Bologna process with new policies and goals such as "student-centred learning which represents both a mindset and a culture within a given higher education institution and is a learning approach which is broadly related to, and supported by, constructivist theories of learning. It is characterised by innovative methods of teaching which aim to promote learning in communication with teachers and other learners and which take students seriously as active participants in their own learning, fostering transferable skills such as problem-solving, critical thinking and reflective thinking. ${ }^{6 "}$ (ESU 2015)

With these changes in tertiary education the teacher and student roles are thought of differently. In the new classroom setting the university teacher should fulfil the role of a facilitator of students' learning by coconstructing their own learning and modelling their learning process (Palmer, 1997). All those interactions between teacher and students constitute a relationship which has a subjective quality and it represents something more than a cognitive and behavioural concern for learning.

\section{The Research and Methodology}

The research was conducted at University of Donja Gorica and its Centre of Foreign Languages where language classes are organized for more than 1000 students who attend at least one language course. The average number of students per group is 15/20 and the number of students who were included in the research was 147. Their proficiency levels were the following English A1/A2 - 38, B1/B2 - 18, C1 - 15; German A1/A2 18, B1/B2 - 15; Spanish A1 - 15; Turkish A1 - 17; Chinese A1 - 11. There were 58 male students and 89 females and they were bachelor and specialist degree students. Out of the total number 14 students participated in semistructured interviews. The central question was to describe the role of the student-teacher relationship in the lives of students at university level. The quantitative part of the research was to investigate how students rate their student-teacher relationship with their current teacher as measured by the

6 Retrieved October 1, 2018 from https://www.esu-online.org/wp-content/uploads/2018/05/11.Student-Centred-Learning.pdf 
ClassMaps Survey (CMS). This ClassMaps Survey used in the current study was developed by Doll, Zucker, and Brehm (2004:18) and it attests that the quality and consistency of the teacher's rapport is "the most essential ingredient in forging a safe, supportive classroom environment". The prompts which were taken into account from the Teacher-Student section of Class Maps Survey (CMS) are as follows:

- My teacher listens carefully to me when I talk.

- My teacher helps me when I need help.

- My teacher respects me.

- My teacher likes having me in this class.

- My teacher makes it fun to be in this class.

- My teacher thinks I do a good job in this class.

- My teacher is fair to me.

As for the qualitative part of the research, it consisted of what values are student-teacher relationships to students, in regard to:

- who they are as a person?

- choices they make at university?

- learning (personal goals)?

- how hard they work on their exams?

- friendships?

- ways they relate to adults?

- behaviors?

- choices they make outside of class?

- how much or how well they study?

- home life or family relationships?

- choices they make outside of class (extracurricular activities, etc.)?

Data was collected in two phases. The first phase was comprised of the collection of quantitative data through the administration of the ClassMaps Survey (CMS).

The second phase of this study consisted of the gathering of qualitative data. The majority of this data was gathered via semi-structured follow-up interviews with 14 of the students (English language courses) who completed the CMS. Responses for each question include: NEVER SOMETIMES - OFTEN - ALMOST ALWAYS. 


\section{Results and Discussion}

The teachers who were described here and the students' answers, shown in the Graph 1, proved that the qualities such as listening (almost always $86 \%$ ), respect (almost always $87 \%$ ) and fairness (almost always $50 \%$ ) are of the greatest importance in establishing a good relationship with students. However, the prompts which lack in TS relationships are helpfulness (never 46\%), the quality of being funny (never 55\%) and encouragement (never 55\%) which are listed as themes most wanted in this kind of relationship also revealed by the second phase of the study.

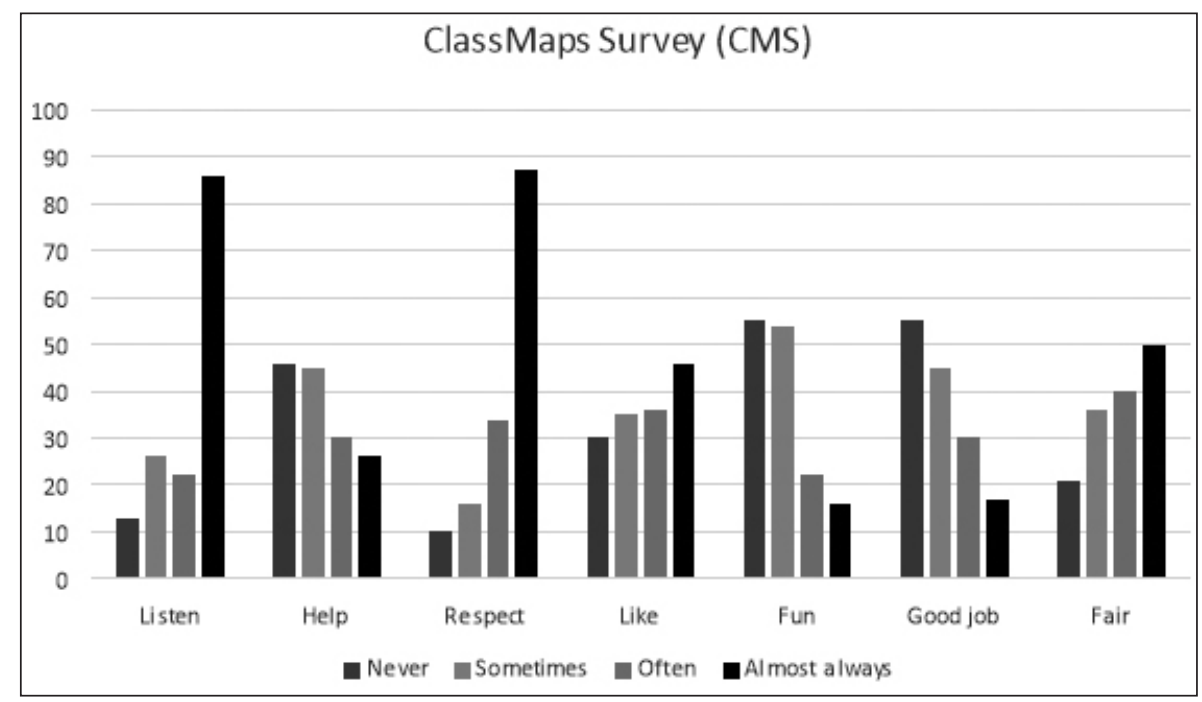

Graph 1. The results of ClassMaps Survey

Table 1. Standard deviation for the prompts: 1,3 and 7.

\begin{tabular}{|c|c|}
\hline Sample Standard Deviation, $\mathrm{s}$ & 21.079215671683 \\
\hline Variance (Sample Standard), $\mathrm{s}^{2}$ & 444.333333333333 \\
\hline Total Numbers, $\mathrm{N}$ & 3 \\
\hline Sum: & 223 \\
\hline Mean (Average): & 74.3333333333333 \\
\hline Standard Error of the Mean $\left(\mathrm{SE}_{\overline{\mathrm{x}}}\right):$ & 12.170090842352 \\
\hline
\end{tabular}


Table 2. Standard deviation for the prompts: 2,5 and 6.

\begin{tabular}{|c|c|}
\hline Sample Standard Deviation, $\mathrm{s}$ & 5.7735026918963 \\
\hline Variance (Sample Standard), $\mathrm{s}^{2}$ & 33.333333333333 \\
\hline Total Numbers, N & 3 \\
\hline Sum: & 155 \\
\hline Mean (Average): & 51.666666666667 \\
\hline Standard Error of the Mean $\left(\mathrm{SE}_{\overline{\mathrm{x}}}\right):$ & 3.3333333333333 \\
\hline
\end{tabular}

The numbers below (Table 3.) show that female participants (63\%) expressed more interest in developing and having strong TS relationships and they tend to care more for the interpersonal relations with their instructor as their guide through the process of learning. It is also observed that female students need more support and encouragement unlike male students.

Table 3 . The correlation between male $(58=39 \%)$ and female $(89=61 \%)$ students:

\begin{tabular}{|c|c|c|c|c|c|c|c|c|}
\hline \multicolumn{7}{|c|}{ The correlation between male (58) and female (89) students: } \\
\hline & \multicolumn{2}{|c|}{ Never } & \multicolumn{2}{c|}{ Sometimes } & \multicolumn{2}{c|}{ Often } & \multicolumn{2}{c|}{ Almost always } \\
\hline & M & F & M & F & M & F & M & F \\
\hline Listen & 10 & 3 & 18 & 18 & 8 & 14 & 22 & 54 \\
\hline Help & 35 & 11 & 10 & 25 & 12 & 18 & 1 & 35 \\
\hline Respect & 6 & 4 & 10 & 11 & 17 & 22 & 25 & 52 \\
\hline Like & 22 & 8 & 10 & 15 & 16 & 20 & 10 & 46 \\
\hline Fun & 32 & 23 & 14 & 40 & 8 & 14 & 4 & 12 \\
\hline Good job & 31 & 24 & 12 & 23 & 10 & 20 & 5 & 22 \\
\hline Fair & 10 & 11 & 15 & 21 & 19 & 21 & 14 & 36 \\
\hline
\end{tabular}


Table 4. The correlation between lower (A1/A2=99/ or $67 \%)$ and higher $(\mathrm{B} 1 / \mathrm{B} 2 / \mathrm{C} 1=48$ or $33 \%)$ levels of proficiency:

\begin{tabular}{|c|c|c|c|c|c|c|c|c|}
\hline \multicolumn{7}{|c|}{$\begin{array}{c}\text { The correlation between lower (A1/A2=99) and higher (B1/B2/C1=48) } \\
\text { levels of proficiency }\end{array}$} \\
\hline & \multicolumn{2}{|c|}{ Never } & \multicolumn{2}{c|}{ Sometimes } & \multicolumn{2}{c|}{ Often } & \multicolumn{2}{c|}{$\begin{array}{c}\text { Almost } \\
\text { always }\end{array}$} \\
\hline & L & H & L & H & L & H & L & H \\
\hline Listen & 13 & 0 & 24 & 2 & 18 & 4 & 44 & 42 \\
\hline Help & 25 & 21 & 24 & 21 & 25 & 5 & 25 & 1 \\
\hline Respect & 10 & 0 & 10 & 6 & 17 & 17 & 62 & 25 \\
\hline Like & 30 & 0 & 25 & 10 & 16 & 20 & 28 & 18 \\
\hline Fun & 52 & 3 & 35 & 19 & 8 & 14 & 4 & 12 \\
\hline Good job & 52 & 3 & 32 & 13 & 10 & 20 & 5 & 12 \\
\hline Fair & 20 & 1 & 29 & 7 & 29 & 11 & 21 & 29 \\
\hline
\end{tabular}

The numbers above (Table 4.) reveal that higher level participants $(87,5 \%)$ expressed less concern for developing and having strong TS relationships as they tend to be more independent during their process of learning. It is also observed that higher level students need less or no help at all while studying and their expectations about teacher's careful listening and a fair teacher are much greater than of lower-level students.

The second phase of this study consisted of the qualitative data which were gathered via semi-structured follow-up interviews with 14 of the students who completed the CMS. Posing the ClassMaps Follow-up Questions allowed for further analysis which brought to light six themes. These themes included common characteristics which different teachers possessed or students wanted their teachers to possess.

\section{- Sense of humor}

The first theme that emerged as valued by the students and possessed by the teachers included a strong sense of humor. Students of English specifically mentioned that some teachers who possessed this quality were able to create a very comfortable learning environment. When teachers bring humour in the class, they help students feel more relaxed, positive and receptive for learning. Maurice (1988: 20-25) quoted from Gagne (1977) and listed eight instructional events that are enhanced through the use of humour:

1. activating motivation

2. informing the learner of the lesson objective 
3. directing attention

4. stimulating recall

5. providing learning guidance

6. enhancing retention

7. promoting the transfer of learning

8. eliciting performance; providing feedback.

\section{- Consistent help}

Students who were interviewed shared different ways in which this help was delivered. Some of the help was given as class was in session, other times it was provided in a small group or individually after class or even before the mid-term or final test. Again, it didn't appear to be important to the students how the help was provided, but that it was consistent and available to all. Not only did students value when their teachers provided the help, they also valued the teachers`encouraging students trying on their own.

\section{- Active listening}

Another theme that emerged from the interviews was the importance of teachers who were actively listening. 11 students chosen for the interviews marked on the CMS that their teachers Almost Always listened to them. When asked how they knew when their teacher was listening to them, the vast majority of the students (nearly 79\%) stressed the importance of being looked at, more specifically looked in the eye, as they spoke. They also shared that the teacher needed to give them both nonverbal feedback, such as nodding one's head; and verbal confirmation that they have understood what the student is saying.

\section{- Value for the whole group as well as the individual}

On the ClassMaps question dealing with fairness (My teacher is fair to me), 10 of the 14 students who were interviewed had marked Almost Always in the survey. When they were asked in the follow-up interview, "Does he/she treat everyone fairly?" and "Is that important to you?" the students unanimously said "yes" to both.

\section{- The inclusion of games for learning}

Students also appreciated when their teachers made learning fun, more specifically when their teachers made games part of the learning process. Twelve students of the 14 interviewed from all of the four years specifically stated that the implementation of games reinforced learning and found it as a reason they felt their teacher made learning fun. 


\section{- The use of spoken and written encouragement}

Two-thirds of the students interviewed expressed that their teachers almost always felt they (the students) did a good job in class. And twothirds valued either spoken or written encouragement or compliments.

\section{Conclusion}

It can be now understood that the student-teacher relationship is experienced with a student and a teacher rather than from a teacher to a student. This student-teacher relationship is more complex at university level than it is thought and it is considered as an embodied and holistic being-togetherin-the-world. Only in this way, a student shall not be the integration of a number of parts but a human who exists completely and bodily alongside and inextricably related to his or her classroom environment. Some educationalists (Bennett, 1997; Palmer, 1997) argue that the student-teacher relationship is more important than the content of education and they advocate for a return to a central focus on relationship rather than the present preoccupation with performance and learning outcomes-based education.

This research has shown that, regardless of the teacher's priorities, the experience of the student-teacher relationship cannot be planned and undervalued but is "authored" in the presently unfolding relational experience. In this context, the student-teacher relationship remains essential despite the priority for academic outcomes in an increasingly dehumanising classroom context.

\section{References:}

Bernstein-Yamashiro, B., and Noam, G. G. (2013). Teacher-student relationships: A growing field of study. New Directions for Youth Development, 2013(137), 15-26.

Bennett, J.B. (1997). The academy, individualism, and the common good. Liberal Education, 83(4):16-24.

Cassidy, J., and Shaver, P. R. (2008). Handbook of attachment: Theory, research, and clinical applications $\left(2^{\text {nd }}\right.$ ed.). New York: Guilford Press.

Collins, W. A., and Repinski, D. J. (1994). Relationships during adolescence: Continuity and change in interpersonal perspective: Personal relationships during adolescence. In R. Montemayor, G. Adams, \& T. Gullotta (Eds.), Advances in adolescent development: Personal relationships during adolescence (Vol. 5, 7-36). Beverly Hills, CA: Sage. 
Cunningham, E. M. (2001). Building connections. Spiritual dimensions of teaching. New York: Peter Lang Publications.

Doll, B., Zucker, S., and Brehm, K. (2004). Resilient Classrooms: Creating Healthy Environments for Learning. New York: Guilford Press.

Gibbs, C. J. (2006). To be a teacher: Journeys towards authenticity. Auckland, New Zealand: Pearson Education.

Harmer, J. (1997). How to teach English. Pearson Education Limited

Kelley, et. al. (1983). Close relationships. San Francisco: Freeman.

Laible, D., and Thompson, R. A. (2007). Early Socialization: ARelationship Perspective. In J. E. Grusec \& P. D. Hastings (Eds.), Handbook of socialization: Theory and research, 181-207. New York, NY, US: Guilford Press.

Martin, A. R. and Forbes, S. H. (2004). What Holistic Education Claims About Itself: An Analysis of Holistic Schools Literature. Paper presented at the American Education Research Association Annual Conference (San Diego, California, April, 2004).

Maurice, K. (1988) Laugh While Learning Another Language: Techniques That Are Functional and Funny. Teaching Forum 26 (2), 20-25.

Miller, J. P. (2000). Education and the soul: Toward a spiritual curriculum. Albany: State University of New York Press.

Otero, G. G., and Chambers-Otero, S. (2000). Relational Learning: Towards a Human Ecology in 21st Century Schools. Jolimont, BC: Incorporated Association of Registered Teachers of Victoria.

Palmer, P. J. (1997). The heart of a teacher: Identity and integrity in teaching. Change, 29(6), 14-21.

Pianta, R. C. (1999). Enhancing relationships between children and teachers. American Psychological Association, Washington DC.

Roorda, et al. (2011). The influence of affective teacher student relationships on students' school engagement and achievement: A meta-analytic approach. Review of Educational Research, 81, 493-529.

Rogers, C. R. (1967) The Interpersonal Relationship in the Facilitation of Learning. In Humanizing Education: The Person in the Process. Ed. T. Leeper. National Education Association, Association for Supervision and Curriculum Development, 1-18.

Vygotsky, L. S. (1978). Mind in society: The development of higher psychological processes. Cambridge, MA: Harvard University Press.

Wentzel, K. R. (2009). Students' relationships with teachers as motivational contexts. In K. R. Wenzel \& A. Wigfield (Eds.), Educational psychology handbook series. Handbook of motivation at school (301-322). New York, NY, US: Routledge/Taylor \& Francis Group. 


\section{Dragica Žugić \\ ZNAČAJ ODNOSA UČENIK-NASTAVNIK IZ PERSPEKTIVE STUDENATA}

Sažetak: Holistički pristup obrazovanju ukazuje na značaj afektivnih i međuodnosnih osobina učenika i nastavnika (Cunningham, 2001; Gibbs, 2006). U savremenoj učionici, i nastavnici i učenici predstavljaju glavne učesnike u procesu obrazovanja, a razgovori o obrazovanju uvijek uključuju primjedbe, anegdote ili priče o posebnim odnosima između nastavnika i učenika. Uticaj odnosa nastavnik-učenik povezan je sa tri različita aspekta učenika: njihovim karakterom, znanjem i razumijevanjem, i vještinama, ili, kako je opisao Palmer (1997), učenikovim “umom, srcem i rukom”. Svrha ovog rada je ispitati ulogu odnosa učenik-nastavnik iz perspektive studenata na univerzitetskom nivou. Kvantitativni podaci prikupljeni su putem ClassMaps ankete (CMS) i analizirani prema dobijenim temama s ciljem sveobuhvatnijeg razumijevanja dinamike i važnosti odnosa učenik-nastavnik u životu studenata na univerzitetskom nivou. Ove teme obuhvatile su sljedeće karakteristike: smisao za humor; stalna pomoć; aktivno slušanje; vrednovanje grupe kao i pojedinca; uključivanje igara u nastavi; i ohrabrenje u usmenoj i pismenoj formi. Pored toga što nastavnicima predstavljaju ciljeve, ove teme se mogu koristiti i kao pomoć HR menadžerima u uspješnijem izboru nastavnika.

Ključne riječi: holistički pristup, uloga nastavnika, odnos učenik-nastavnik, relacijska povezanost 